\title{
PERHITUNGAN BEBAN PENDINGINAN PADA SISTEM REFRIGERASI AIR BLAST FREEZER
}

\section{(CALCULATION OF THE COOLING LOAD IN THE AIR BLAST FREEZER)}

\author{
Boby Wisely Ziliwu ${ }^{1 *}$, Juniawan Preston Siahaan ${ }^{2}$, Uriandi ${ }^{3}$ \\ 1,2,3 Permesinan Kapal Politeknik Kelautan dan Perikanan Dumai, \\ Jl Wan Amir No.1, Kel. Pangkalan Sesai, Kec. Dumai Barat, Dumai, Riau 28826, Indonesia \\ *) Korespondensi : bobyziliwu@gmail.com
}

\begin{abstract}
Abstrak
Refrigerasi merupakan suatu usaha pemeliharaan tingkat suhu dari suatu bahan atau ruangan pada tingkat yang lebih rendah dari suhu lingkungan disekitarnya dengan cara penyerapan panas dari bahan atau ruangan tersebut. Secara singkat dapat dikatakan bahwa refrigerasi adalah proses pemindahan panas dari suatu bahan atau ruangan lainnya. Pada dasarnya teknologi refrigerasi adalah pengolahan panas. Proses refrigerasi tidak terlepas dari masalah beban pendinginan selama mesin refrigerasi beroperasi. Beban pendingin yang berlebih pada suatu unit refrigerasi tentu akan berpengaruh yaitu dapat mempercepat proses pembusukan atau penurunan mutu hasil tangkapan. Penelitian ini bertujuan untuk menghitung beban pendingin air blast freezer dan mengetahui komponen-komponen refrigerasi unit air blast freezer. Dari hasil penelitian yang didapat, bahwa kapal yang sistem refrigerasinya mempunyai Daya pendingin sebesar $30 \mathrm{~kW}$ mampu mendinginkan ikan sebanyak 3,5 Ton $(3.500 \mathrm{~kg})$. Dengan beban pendingin 1 ruang $\mathrm{ABF}$ sebesar 28,54 kW dengan massa ikan $3.500 \mathrm{~kg}$. untuk $\mathrm{COP}_{\text {actual }}$ yang dicapai oleh air blast freezer tersebut adalah sekitar 2,8 lebih kecil dari $\mathrm{COP}_{\text {carnot }}$ sebesar 6,1 .
\end{abstract}

Kata Kunci: Air Blast Freezer, Refrigerasi, Daya, Ikan, Panas

\begin{abstract}
Refrigeration is an attempt to maintain the temperature level of a material or room at a level lower than the temperature of the surrounding environment by absorbing heat from the material or room. In short it can be said that refrigeration is the process of transferring heat from a material or another room. Basically, refrigeration technology is heat treatment. The refrigeration process is inseparable from the cooling load problem during the refrigeration machine operates. Excessive cooling load on a refrigeration unit will certainly have an effect that can accelerate the process of decomposition or deterioration in the quality of the catch. This research aims to calculate the cooling load of the blast freezer water and determine the refrigeration components of the blast freezer water unit. From the research results obtained, that the ship whose refrigeration system has a cooling power of $30 \mathrm{~kW}$ is able to cool fish as much as 3.5 tons $(3,500 \mathrm{~kg})$. With a cooling load of $1 \mathrm{ABF}$ space of $28.54 \mathrm{~kW}$ with a fish mass of 3,500 kg. the COP actual achieved by the blast freezer water is about 2.8 smaller than the COP carnot $_{\text {of } 6.1 \text {. }}$
\end{abstract}

Keywords: Air Blast Freezer, Refrigeration, Power, Fish, Heat. 


\section{PENDAHULUAN}

Refrigerasi merupakan suatu usaha pemeliharaan tingkat suhu dari suatu bahan atau ruangan pada tingkat yang lebih rendah dari suhu lingkungan disekitarnya dengan cara penyerapan panas dari bahan atau ruangan tersebut. Secara singkat dapat dikatakan bahwa refrigerasi adalah proses pemindahan panas dari suatu bahan atau ruangan lainnya. Proses refrigerasi tidak terlepas dari masalah beban pendinginan selama mesin refrigerasi beroperasi. Beban pendingin yang berlebih pada suatu unit refrigerasi tentu akan berpengaruh yaitu dapat mempercepat proses pembusukan atau penurunan mutu hasil tangkapan. Dengan adanya freezer ini dapat menjaga mutu dan kualitas dari ikan hasil tangkapan pada saat berada diatas laut sampai berada di pelabuhan. Ikan hasil tangkapan harus memerlukan perlakuan kusus dengan cara didinginkan supaya dapat terjaga kualitasnya. Semakin bagus kualitas ikan maka semakin tinggi harga jual ikan hasil tangkapan tersebut, hal ini secara tidak langsung akan mampu meningkatkan kesahjateraan nelayan. Proses pendinginan ikan bertujuan untuk menghambat tumbuh dan berkembangnya bakteri yang dapat menyebabkan kesegaran ikan menjadi rusak. Dalam pengoperaian mesin refrigerasi dilakukan menejemen pemeliharaan beban yang baik sehingga produk yang didinginkan dapat dibekukan dengan tetap memperhatikan usaha penghematan beban pendingin pada sistem refrigerasi tersebut. Pada penelitian ini, akan difokuskan bagaimana menghitung beban pendingin air blast freezer. Beban yang dihitung berupa kan hasil tangkapan yang akan dimasukkan ke dalam air blast freezer. Selain menghitung beban-beban pada ikan, akan diketahui juga komponen-komponen apa saja yang terdapat pada unit refigerasi air blast freezer.

\section{METODE}

\section{a. Pelaksanaan Penelitian}

Penelitian ini dilaksanakan kurang lebih selama 3 bulan terhitung mulai dari bulan Maret hingga Juni 2020. Adapun pengambilan data dilakukan diatas kapal KM Mitra Lestari yang berlayar di sekitar laut Juwana, Pati Jawa Tengah.

\section{b. Sumber Data}

Dalam pelaksanaan penelitian ini metode yang dilakukan dengan cara pengamatan langsung dan wawancara dengan kapten kapal, kepala kamar mesin refirgerasi dan Anak Buah Kapal (ABK). Sedangkan pengamatan yang dilakukan adalah mengamati setiap kegiatan yang dilakukan diatas kapal untuk memastikan keterangan penulis memperoleh dari kapten kapal, kepala kamar mesin dan anak buah kapal.

\section{c. Teknik Pengumpulan Data}

Pengumpulan data dilakukan dengan dua cara, yakni data primer dan data sekunder.

\section{Data Primer}

Data primer diperoleh dengan melakukan pengamatan dan mengikuti seluruh kegiatan yang berlangsung diatas kapal, baik perawatan dan perbaikan mesin kapal.

\section{Data sekunder}

Data sekunder dilakukan dengan studi literature yang digunakan sebagai bahan acuan atau pembanding dengan hasil penulis selama mengambil data.

\section{d. Analisis Data}

Analisis data yang digunakan adalah analisa untuk menghitung beban pada ruangan pendingin (refrigeration) diatas kapal. Alat yang digunakan selama melakukan penelitian adalah : 1. Air Blast Freezer

Merupakan tipe pembekuan yang umum, dimana ruang pendingin diisi dengan udara yang didinginkan. Keuntungannya adalah temperatur dingin dapat disebarkan hingga ke sudut ruangan secara efisien, dengan memanfaatkan aliran konveksi, namun koefisien transfer panas konvektif udara cenderung kecil sehingga pembekuan perlu dilakukan dalam waktu yang lebih lama akibat rendahnya laju transfer panas. Semakin besar ruangan, semakin kecil kalor yang dapat dipindahkan dalam satuan waktu tertentu. Hilangnya berat dari produk juga dapat terjadi akibat kontak langsung antara produk dan air yang mampu untuk mengangkat kandungan air dalam produk makanan, terutama jika temperatur dan kelembaban memungkinkan.

2. Peralatan tulis

Alat tulis yang digunakan untuk menulis data-data kapal yang diperlukan selama melakukan penelitian.

3. Smartphone 
Alat yang digunakan untuk pengambilan gambar pada unit atau objek yang diperlukan.

4. Alat tangkap Purse Seine

Merupakan alat yang digunakan untuk penangkapan ikan di laut.

5. Termometer

Alat yang digunakan untuk mengukur suhu

6. Manometer

Alat yang digunakan untuk mengukur tekanan

Bahan yang digunakan selama penelitian adalah:

1. Bahan bakar

Bahan bakar digunakan untuk memperlancarkan pengoperasian mesin induk dan generator.

2. Bahan Pendingin

Freon merupakan bahan yang digunakan untuk pendinginan pada refrigerasi.

\section{e. Proses Kompresi di Kompresor}

Uap refrigeran tersebut menjadi bertekanan tinggi sebagai akibat dari kerja yang diberikan kompresor kepada refrigeran (W). Besarnya kerja kompresi tersebut dapat dihitung berdasarkan data dari siklus refrigerasi kompresi uap tersebut pada diagram Tekanan Entalphy (P-h).

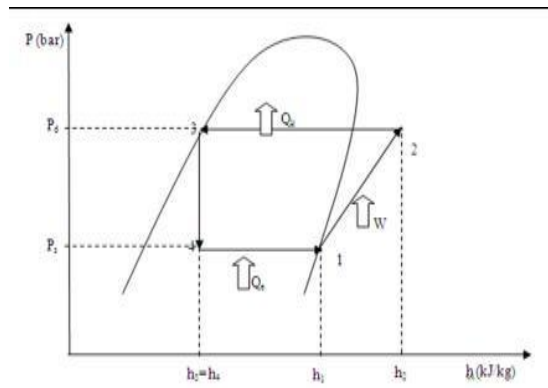

Gambar 1. Siklus refrigerasi pada diagram tekanan-entalpi

Maka berdasarkan gambar 1 diatas, kerja kompresi oleh kompresor dapat dihitung dengan rumus berikut:

$$
\mathrm{W}_{\text {KOMPRESOR }}=\mathrm{m}(\mathrm{h} 2-\mathrm{h} 1)
$$

$$
\mathrm{W} \text { Komp }=\text { kerja kompresor, } \mathrm{kJ}
$$

Keterangan :

$\mathrm{m}=$ massa refrigerant yang melewati kompresor $(\mathrm{Kg})$

h2 = Entalpi Refirgerant keluaran kompresor, $(\mathrm{kJ} / \mathrm{Kg})$ $\mathrm{h} 1=$ Entalpi refrigerant masukan kompresor, $(\mathrm{kJ} / \mathrm{Kg})$

Dengan kata lain kerja kompresor dihitung dari selisih antara entalpi refrigeran keluaran dan masukan kompresor dikalikan dengan massa refrigeran yang melewatinya. Karena refrigeran yang melewati kompresor mengalir dengan kecepatan tertentu, akan sulit sekali untuk menghitung sejumlah massa refrigeran yang melewatinya. Maka akan lebih efektif jika persamaan 1.2 dinyatakan dalam satuan energi per satuan waktu (daya) dengan cara mengalikan selisih entalpi keluar dan masuk dengan laju aliran massa refrigeran yang mengalir, yaitu:

$$
\mathrm{PKompr}=\mathrm{m}(\mathrm{h} 2-\mathrm{h} 1) \ldots . .2 .2
$$

\section{Pkompr $=$ Daya mekanik kompresor $(\mathrm{W})$}

Persamaan 2.2 diatas merupakan rumus untuk menghitung nilai daya mekanik dari kompresor, yaitu kerja yang disebabkan oleh gerakan piston kompresor. Dalam istilah mesin daya ini sering disebut dengan daya output (Po).

\section{f. Laju penyerapan panas (kapasitas) di Evaporator}

Refrigeran yang mengalir di evaporator sebagian besar berfasa cair dan bertemperatur lebih rendah dari temperatur lingkungan. Selanjutnya refrigeran tersebut menyerap kalor dari lingkungan sekitar yang mengakibatkan semua refrigeran cair pada evaporator tersebut menguap kembali menjadi fasa gas. Sejumlah panas yang diserap di evaporator tersebut dapat dihitung juga berdasarkan data dari siklus refrigerasi kompresi uap pada diagram Tekanan - Entalpi (P-h diagram). Dan berdasarkan gambar 1 di atas besarnya laju panas yang diserap di evaporator dapat dihitung dengan menggunakan rumus berikut:

$$
\mathrm{Qe}=\mathrm{m}(\mathrm{h} 1-\mathrm{h} 4) \ldots . .2 .3
$$

\section{$\mathrm{Qe}=$ panas evaporator}

Selain kerja kompresor dan kapasitas penyerapan panas di evaporator, pada system refrigerasi kompresi uap juga dikenal istilah coeffisien of performance (COP) yang mana nilai COP tersebut merupakan suatu nilai perbandingan antara kapasitas penyerapan panas yang terjadi di evaporator dengan 
sejumlah kerja kompresi yang dilakukan di kompresor.

$$
\text { COPaktual }=\frac{\mathrm{Qe}}{\text { Pkomp }} \ldots \ldots .2 .4
$$

COPaktual $=\mathrm{COP}$ yang sebenarnya terjadi

Nilai COP tersebut merupakan nilai COP aktual atau yang sebenarnya terjadi. Terdapat juga istilah COP carnot, dimana merupakan nilai COP yang ideal dengan menganggap bahwa kalor yang dilepas di kondensor adalah sama dengan kalor yang diambil di evaporator ditambah energi yang dikeluarkan di kompresor. Sehingga rumus COP Carnot ini adalah :

$$
\text { COPcarnot }=\frac{\text { Tevaporasi }}{\text { Tkondensasi-Tevaporasi }} \ldots 2.5
$$

COPcarnot $=$ cop yang ideal

Tevaporasi $=$ tekanan evaporator, bar

Tkondensasi = tekanan kondensor, bar

\section{g. Perhitungan Beban Konduksi Melewati Dinding}

Terjadinya perpindahan panas dari udara luar kedalam ruangan dinding sebagai adanya perbedaan temperature antara sisi luar dinding dengan sisi bagian dalam

$$
\begin{aligned}
& \text { QWall = A.U. } \Delta \mathrm{T} \ldots . .2 .6 \\
& \text { Qwall = panas diding } \\
& \mathrm{A}=\text { luas dinding total, } \mathrm{m}^{2} \\
& \mathrm{U}=\text { Jumlah energi panas yang melewati } \\
& \quad \text { dinding, } \mathrm{kW} \\
& \Delta \mathrm{T}=\text { suhu akhir, }{ }^{\circ} \mathrm{C}
\end{aligned}
$$

Koefisien perpindahan panas menyeluruh (U) dapat diartikan sebagai jumlah energi panas yang dapat berpindah melewati dinding seluas 1 $\mathrm{m}$ dalam setiap $1^{\circ} \mathrm{C}$ perbedaan temperatur pada dinding. Dimana nilai ini tergantung dari ketebalan dinding dan material dinding yang digunakan pada ruangan tersebut. Perhatikan Gambar 2, rumus untuk gambar tersebut adalah:

$$
\frac{1}{h_{a} \cdot A} \cdot\left(\frac{x_{1}}{k_{1} A}+\frac{x_{2}}{k_{2} A}+\frac{x_{3}}{k_{3} A}\right) \frac{1}{h_{b} \cdot A}
$$

Udara luar pada posisi A temperaturnya lebih tinggi daripada udara dalam (posisi B) sehingga panas mengalir dari udara A ke B. Udara pada posisi A dan B masing - masing memiliki koefisien konveksi $\mathrm{Ha}$ dan $\mathrm{h}$ Sedangkan luas permukaan dinding A dan panas yang melewati dinding $\mathrm{Q}$.

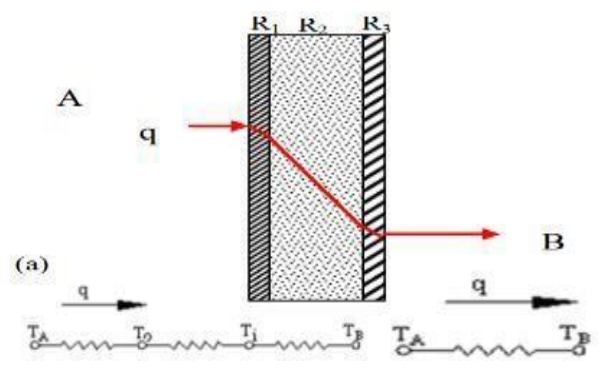

Gambar 2. Perpindahan panas pada dinding

Bentuk lain dari persamaan 2.7 diatas adalah sebagai berikut:

$$
\mathrm{Q}_{\mathrm{wall}}=\frac{A(\Delta T)}{\frac{1}{h_{a}}+\frac{x_{1}}{k_{1}}+\frac{x_{2}}{k_{2}}+\frac{x_{3}}{k_{3}}+\frac{1}{h_{b}}} \cdots 2.8
$$

Keterangan :

$$
\begin{aligned}
\mathrm{ha}= & \text { koefisien perpindahan panas konveksi } \\
& \text { permukaan dinding }\left(\mathrm{W} / \mathrm{m}^{2}{ }^{\circ} \mathrm{C}\right) \\
\mathrm{hb}= & \text { koefisien perpindahan panas konveksi } \\
& \text { permukaan atap }\left(\mathrm{W} / \mathrm{m}^{2}{ }^{\circ} \mathrm{C}\right) \\
\mathrm{x}= & \text { ketebalan material } \\
\mathrm{k}= & \text { konduktifitas material }
\end{aligned}
$$

\section{h. Perhitungan Beban Produk}

Jika temperatur penyimpanan produk lebih rendah dari temperatur titik bekunya, maka jenis panas yang di keluarkan oleh produk tersebut terdiri dari tiga jenis yaitu :

1. Panas sensibel sebelum pembekuan, merupakan yang dikeluarkan oleh produk penurunan temperatur produk tersebut sampai pada batas temperatur titik bekunya

2. Panas laten pembekuan, yaitu panas yang dikeluarkan ketika terjadi perubahan wujud produk dari cair menjadi padat (beku).

3. Panas sensibel setelah pembekuan, merupakan panas yang dikeluarkan produk akibat penurunan temperatur dari temperatur titik beku hingga pada temperatur yang lebih rendah lagi (minus)

Besarnya panas sensible dari produk tersebut dapat dihitung dengan:

Qs.prod $=\mathrm{m} . \mathrm{Cp}(\Delta \mathrm{T})$

Keterangan : 
Qs.Prod $=$ panas sensibel produk $(\mathrm{kJ})$

$\mathrm{M} \quad=$ massa ikan yang masuk $(\mathrm{Kg})$

$\mathrm{Cp} \quad=$ Panas spesifik setelah beku ikan $(\mathrm{kJ} / \mathrm{Kg})$

$\Delta \mathrm{T}=$ perbedaan temperature $\left({ }^{\circ} \mathrm{C}\right)$

\section{i. Perhitungan beban motor listrik}

Jenis panas lain yang ada pada ruang penyimpanan dingin adalah panas yang dihasilkan dari peralatan listrik penghasil panas yang ada di dalam ruangan. Biasanya peralatan listrik yang ada di dalam ruangan tersebut hanya berupa motor kipas evaporator.

motor heat gain $=\mathrm{w}=\mathrm{kw}$
Qmotor $=\mathrm{kW}$ x jumlah kipas

Qmotor = panas motor kipas evaporator $(\mathrm{kW})$

\section{j. Cooling Rate (Laju Pendinginan)}

Cooling Rate yaitu laju pendinginan maksimum yang tidak memotong nose dari kurva S, yang artinya bahwa laju pendinginan maksiumum dimana masih bisa berbentuk struktural material berupa matensit.

\section{HASIL DAN PEMBAHASAN}

\section{Hasil Tangkapan}

Kapal KM. Mitra Lestari beroperasi dilaut Papua yang target masa berlayar selama 6 bulan. Kapal ini memiliki alat tangkap purse seine yang beroperasi pada malam hari. Berikut data yang diperoleh:

Tabel 1. Hasil Tangkapan

\begin{tabular}{|c|c|c|c|}
\hline No & $\begin{array}{c}\text { Nama } \\
\text { jenis } \\
\text { ikan }\end{array}$ & $\begin{array}{c}\text { Jumlah } \\
(\mathrm{kg})\end{array}$ & $\begin{array}{c}\text { Penanganan } \\
\text { diatas kapal } \\
\text { (segar/beku/asin) }\end{array}$ \\
\hline 1 & Tongkol & 80.000 & Beku \\
\hline 2 & Banyar & 110.000 & Beku \\
\hline 3 & Layang & 60.000 & Beku \\
\hline
\end{tabular}

Berikut adalah gambar hasil tangkapan ikan:

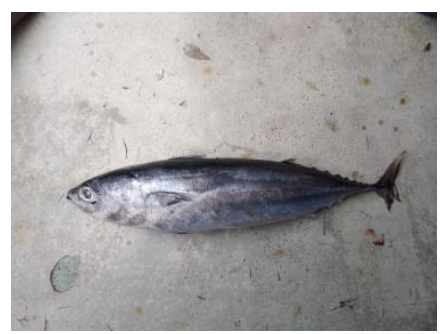

Gambar 3. Ikan Tongkol

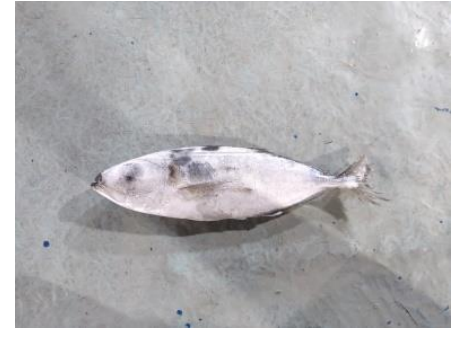

Gambar 4. Ikan Banyar

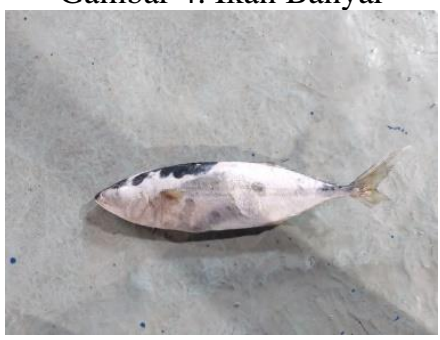

Gambar 5. Ikan Layang

\section{Perhitungan COP, Kapasitas Pendingin, dan Efisiensi Refrigerasi}

Untuk mempermudah perhitungan maka data yang sudah ditentukan diatas diagram tekanan entalpi (p-h). berdasarkan pada data yang ada, kita dapat mengetahui kinerja sistem yang kemudian dianalisis dan dibandingkan dengan kondisi rancangan.

Tabel 2. Hasil Data Air Blast Freezer

\begin{tabular}{|c|c|c|c|}
\hline No & Objek data & Tekanan(bar) & Temperatur $\left({ }^{\circ} \mathrm{c}\right)$ \\
\hline 1 & Tdischarge & 15 & \\
\hline 2 & Tsuction & 1,4 & \\
\hline 3 & Tempdischarge & & 110 \\
\hline 4 & Tempsuction & & -5 \\
\hline 5 & Tempmasukevaporator & & -20 \\
\hline 6 & Temp keluar kondesor & & 40 \\
\hline 7 & & & \\
\hline 8 & Tempevaporator & & -1 \\
\hline
\end{tabular}

Jika diplotkan ke diagram p-h r-22 diperoleh harga-harga entalpi sebagai berikut:

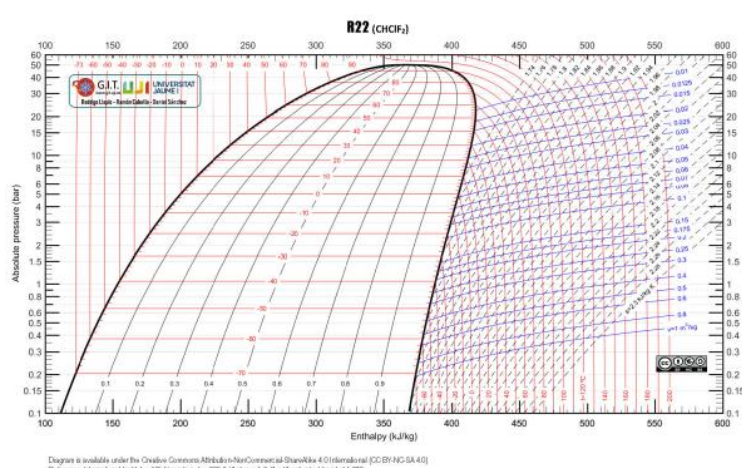

Gambar 6. Diagram Entalpi R22 


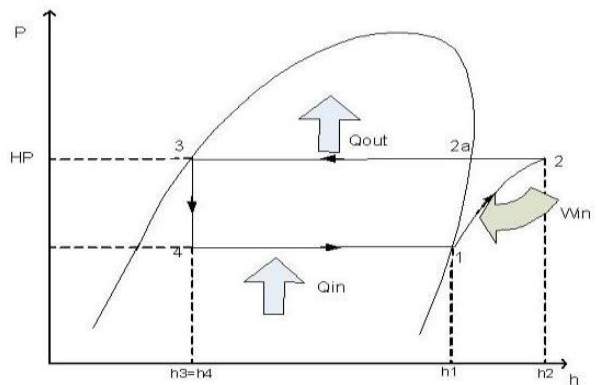

Gambar 7. Diagram Perhitungan

Berdasarkan dari perhitungan diagram entalpi r-22 didapat data sebagai berikut:

$\mathrm{h}_{1}=390 \mathrm{~kJ} / \mathrm{Kg}$

$\mathrm{h}_{2}=440 \mathrm{~kJ} / \mathrm{Kg}$

$\mathrm{h}_{3}=\mathrm{h}_{4}=250 \mathrm{~kJ} / \mathrm{Kg}$

Pkomp $=28,54 \mathrm{~kW}$ (Beban Kompresor)

$\mathrm{M}=$ Pkomp $/ \mathrm{h}_{2}-\mathrm{h}_{1}$

$=28,54 / 440-390$

$=0,5708 \mathrm{Kg} / \mathrm{s}$

Berdasarkan pada persamaan 2.3 kapasitas pendingin di evaporator:

$$
\begin{aligned}
\mathrm{Qe} & =\mathrm{m}\left(\mathrm{h}_{1}-\mathrm{h}_{4}\right) \\
& =0,5708(390-250) \\
& =79,912 \mathrm{~kW}
\end{aligned}
$$

COPaktual $=\frac{\mathrm{Qe}}{\text { Pkomp }}$

$$
\begin{aligned}
& =\frac{79,912 \mathrm{~kW}}{28,54 \mathrm{~kW}} \\
& =2,8
\end{aligned}
$$

COPcarnot $=\frac{\text { Tevaporator }}{\text { Trandensasi-Tevapor }}$

$$
\begin{gathered}
=\frac{\text { Tkondensasi-Tevaporator }}{=\frac{273-(-1)}{45-(-1)}} \\
=6,1
\end{gathered}
$$

Пrefrigerasi $=\frac{\text { COPaktual }}{\text { COPcarnot }} \times 100 \%$

$$
\begin{aligned}
& =\frac{2,8}{6,1} \times 100 \% \\
& =45,9 \%
\end{aligned}
$$

\section{Panas yang melewati dinding}

Berdasarkan dari data ruang pendingin, perhitungan jumlah panas yang melewati dinding $\mathrm{ABF}$ tersebut dapat dihitung dari data spesifikasi dapat dilihat pada tabel 3 .

Tabel 3. Data Dinding dan Atap

\begin{tabular}{|c|c|c|}
\hline No & Objek data & Luas $\left(\mathrm{m}^{2}\right)$ \\
\hline 1 & $\begin{array}{c}\text { Luas dinding sebelah } \\
\text { utara }\end{array}$ & 12 \\
\hline 2 & $\begin{array}{c}\text { Luas dinding sebelah } \\
\text { selatan }\end{array}$ & 9 \\
\hline 3 & $\begin{array}{c}\text { Luas dinding sebelah } \\
\text { barat }\end{array}$ & 9 \\
\hline 5 & $\begin{array}{c}\text { Luas dinding sebelah } \\
\text { timur }\end{array}$ & 12 \\
\hline 6 & Luas total dinding \\
\hline
\end{tabular}

Koefisien perpindahan panas konveksi permukaan dinding $=4,628 \mathrm{w} / \mathrm{m}^{2}{ }^{\circ} \mathrm{C}$ Koefisien perpindahan panas konveksi permukaan atap $\quad=4,628 \mathrm{w} / \mathrm{m}^{2}{ }^{\circ} \mathrm{C}$

Material dinding :

$>0,5 \mathrm{~mm}$ fiberglass, dengan nilai $\mathrm{k}=0,035$ $\mathrm{W} / \mathrm{m}^{2}{ }^{\circ} \mathrm{C}$

$>70 \mathrm{~mm}$ kayu, dengan nilai $\mathrm{k}=0,15 \mathrm{~W} / \mathrm{m}^{2}$ ${ }^{\circ} \mathrm{C}$

$>0,5 \mathrm{~mm}$ fiberglass, dengan nilai $\mathrm{k}=0,035$ $\mathrm{W} / \mathrm{m}^{2}{ }^{\circ} \mathrm{C}$

Untuk luas dinding sebelah utara:

$\Delta \mathrm{T}=$ Temp. Lingkungan - Temp. ABF $=37^{\circ} \mathrm{C}-\left(-20^{\circ} \mathrm{C}\right)=57^{\circ} \mathrm{C}$

Untuk luas dinding sebelah selatan,barat dan timur:

$\Delta \mathrm{T}=\mathrm{Temp}$. Lingkungan - Temp. ABF

$$
=26{ }^{\circ} \mathrm{C}-\left(-20^{\circ} \mathrm{C}\right)=46^{\circ} \mathrm{C}
$$

Untuk luas atap:

$\Delta \mathrm{T}=\mathrm{Temp}$. Lingkungan - Temp. ABF $=34^{\circ} \mathrm{C}-\left(-20^{\circ} \mathrm{C}\right)=54^{\circ} \mathrm{C}$

Sehingga besarnya perpindahan panas yang melewati dinding dapat dihitung dengan rumus berikut:

$$
\begin{gathered}
\text { Qdinding utara }=\frac{A(\Delta T)}{\frac{1}{h a}+\frac{x 1}{k 1}+\frac{x 2}{k 2}+\frac{x 3}{k 3}+\frac{1}{h b}} \\
=\frac{12(57)}{\frac{1}{4,628}+\frac{0,0005}{0,035}+\frac{0,7}{0,15}+\frac{0,0005}{0,035}+\frac{1}{4,628}} \\
=\frac{684}{5,068} \\
=0,134 \mathrm{~kW}
\end{gathered}
$$

Qdinding selatan $=\frac{A(\Delta T)}{\frac{1}{h a}+\frac{x 1}{k 1}+\frac{x 2}{k 2}+\frac{x 3}{k 3}+\frac{1}{h b}}$

$$
\begin{aligned}
& =\frac{1}{\frac{1}{4,628}+\frac{0,0005}{0,035}+\frac{0,7}{0,15}+\frac{0,0005}{0,035}+\frac{1}{4,628}} \\
& =\frac{552}{5,068} \\
& =0,108 \mathrm{~kW}
\end{aligned}
$$

Qdinding timur $=\frac{A(\Delta T)}{\frac{1}{h a}+\frac{x 1}{k 1}+\frac{x 2}{k 2}+\frac{x 3}{k 3}+\frac{1}{h b}}$

$$
\begin{aligned}
& =\frac{9(46)}{\frac{1}{4,628}+\frac{0,0005}{0,035}+\frac{0,7}{0,15}+\frac{0,0005}{0,035}+\frac{1}{4,628}} \\
& =\frac{414}{5,068} \\
& =0,81 \mathrm{~kW}
\end{aligned}
$$

Qdinding barat $=\frac{A(\Delta T)}{\frac{1}{h a}+\frac{x 1}{k 1}+\frac{x 2}{k 2}+\frac{x 3}{k 3}+\frac{1}{h b}}$

$$
\begin{aligned}
& =\frac{9(46)}{\frac{1}{4,628}+\frac{0,0005}{0,035}+\frac{0,7}{0,15}+\frac{0,0005}{0,035}+\frac{1}{4,628}} \\
& =\frac{414}{5,068} \\
& =0,81 \mathrm{~kW}
\end{aligned}
$$


Dari perhitungan setiap sisi dinding dapatlah panas total dinding dengan menjumlahkan setiap sisi:

$\mathrm{Q}$ total dinding $=\mathrm{Q}$ dinding utara $+\mathrm{Q}$ dinding selatan $+\mathrm{Q}$ dinding timur $+\mathrm{Q}$ dinding barat

$=0,134+0,108+0,81+0,81$

$=0,404 \mathrm{~kW}$

Dan melalui atap.

$$
\begin{aligned}
\text { Qatap } & =\frac{A(\Delta T)}{\frac{1}{h a}+\frac{x 1}{k 1}+\frac{x 2}{k 2}+\frac{x 3}{k 3}+\frac{1}{h b}} \\
& =\frac{\frac{1}{4,628}+\frac{0,0005}{0,035}+\frac{0,7}{0,15}+\frac{0,0005}{0,035}+\frac{1}{4,628}}{5,068} \\
& =0,127 \mathrm{~kW}
\end{aligned}
$$

\section{Panas Dari Produk}

Jenis panas dari ikan yang akan diidinginkan Pada ABF hanya panas sensible sebelum pembekuan yaitu panas sensible yang dikeluarkan dari penurunan temperatur awal ikan $30{ }^{\circ} \mathrm{C}$ hingga temperatur beku $-5^{\circ} \mathrm{C}$. pada perhitungan panas yang dihasilkan oleh ikan ini memerlukan data kalor sepesifik dari ikan itu sendiri, maka nilainya diambil dari ikan yang paling banyak disimpan diruang pendingin yaitu dipilih jenis ikan tongkol. Data ikan panas $\mathrm{CP}$ dapat dilihat pada tabel 4.

Tabel 4. Data ikan panas

\begin{tabular}{|c|c|c|c|c|}
\hline No & $\begin{array}{c}\text { Jenis } \\
\text { ikan }\end{array}$ & $\begin{array}{c}\text { Suhu } \\
\text { awal- } \\
\text { akhir }\left({ }^{\circ} \mathrm{C}\right)\end{array}$ & $\begin{array}{c}\text { Panas } \\
\text { spesifik(cp) }\end{array}$ & $\Delta \mathrm{T}$ \\
\hline 1 & Tongkol & $27-(-1)$ & 3,550 & 28 \\
\hline 2 & Banyar & $26-(-3)$ & 3,518 & 29 \\
\hline 3 & Layang & $25-(-3)$ & 3,520 & 28 \\
\hline
\end{tabular}

Sehingga jumlah kalor yang diserap dievaporator pada $\mathrm{ABF}$ yaitu:

Ikan tongkol

Qs.produk $=\mathrm{m} . \mathrm{c} \cdot \Delta \mathrm{T}$

$$
\begin{aligned}
& =1300 \times 3,550 \times 28 \\
& =129,220 \mathrm{~kJ}
\end{aligned}
$$

Ikan banyar

Qs.produk $=$ m.c. $\Delta \mathrm{T}$

$$
\begin{aligned}
& =1400 \times 3,518 \times 29 \\
& =142,830 \mathrm{~kJ}
\end{aligned}
$$

Ikan layang

Qs.produk $=$ m.c. $\Delta \mathrm{T}$

$$
\begin{aligned}
& =800 \times 3,520 \times 28 \\
& =78,848 \mathrm{~kJ}
\end{aligned}
$$

Qs.produktotal $=129,220+142,830+78,848$

$$
=350,898 \mathrm{~kJ}
$$

Sejumlah kalor tersebut telah didinginkan secara setahap dengan jumlah ikan $3500 \mathrm{~kg}$ dalam waktu 18 jam, jadi beban produk yang tertera diatas jika dikonversi dalam satuan kilowatt adalah sebagai berikut:

Qs.produk $=350,898 \mathrm{~kJ} /(18 \mathrm{jam} \times 3600$

$$
\begin{aligned}
& \mathrm{s}, \mathrm{jam}) \\
= & 5,41 \mathrm{~kW}
\end{aligned}
$$

Panas produk pada titik tengah menuju titik akhir yang disebut panas laten dan panas sensible setelah pembekuan, sehingga pada perhitungan panas di palka penyimpanan memerlukan data kalor spesifik setelah pembekuan dan kalor laten dari ikan itu sendiri. Data panas ikan (hlf) dapat dilihat pada tabel 5 .

Tabel 5. Data ikan panas (hlf)

\begin{tabular}{|c|c|c|c|c|c|}
\hline No & $\begin{array}{c}\text { Jenis } \\
\text { ikan }\end{array}$ & $\begin{array}{c}\text { Suhu } \\
\text { awal- } \\
\text { akhir }\left({ }^{\circ} \mathrm{c}\right)\end{array}$ & $\begin{array}{c}\text { Panas } \\
\text { spesifik(cp) }\end{array}$ & $\Delta \mathrm{T}$ & $\begin{array}{c}\text { Panas } \\
\text { laten(hlf) }\end{array}$ \\
\hline 1 & Tongkol & $(-1)-(-10)$ & 3,534 & 9 & 227 \\
\hline 2 & Banyar & $(-3)-(-13)$ & 3,502 & 10 & 227 \\
\hline 3 & Layang & $(--3)-(-13)$ & 3,510 & 10 & 227 \\
\hline
\end{tabular}

QL.prod tongkol $=\mathrm{m} \cdot \mathrm{hlf}$

$$
\begin{aligned}
& =1300.227 \\
& =295.100 \mathrm{~kJ}
\end{aligned}
$$

QS.prod

$$
=\operatorname{m} \cdot \operatorname{Cp}(\Delta \mathrm{T})
$$$$
=1300 \cdot 3,534(9)
$$$$
=41,347 \mathrm{~kJ}
$$

Qproduk = QL.prod + QS.prod

$$
=295,141 \mathrm{~kJ}
$$

QL.prod banyar $=\mathrm{m}$.hlf

$$
\begin{aligned}
& =1400.227 \\
& =317.800 \mathrm{~kJ}
\end{aligned}
$$

QS.prod $=\mathrm{m} . \mathrm{Cp}(\Delta \mathrm{T})$

$=1400 \cdot 3,502(10)$

$=49,028 \mathrm{~kJ}$

Qproduk = QL.prod + QS.prod

$$
=317,849 \mathrm{~kJ}
$$

QL.prod layang $=$ m.hlf

$$
\begin{aligned}
& =800.227 \\
& =181.600 \mathrm{~kJ} \\
\text { QS.prod } \quad & \mathrm{m} \cdot \mathrm{Cp}(\Delta \mathrm{T}) \\
& =800.3,510(10) \\
& =28,080 \mathrm{~kJ}
\end{aligned}
$$

Qproduk $=$ QL.prod + QS.prod

$$
=181,628 \mathrm{~kJ}
$$

$\mathrm{Q}$ total prod $=\mathrm{Q}$ prod tongkol+ $\mathrm{Q}$ prod banyar + Q prod layang 
$=295,141 \mathrm{~kJ}+317,849 \mathrm{~kJ}+181,628 \mathrm{~kJ}$

$=794,618 \mathrm{~kJ}$

Dikarenakan sejumlah panas dari produk akan didinginkan dalam waktu 10 jam, makan beban keseluruhan jika dikonveksikan ke dalam satuan $\mathrm{kW}$ adalah.

Qproduk $=794,618 \mathrm{~kJ} /(10 \mathrm{jam} \times 3600 \mathrm{~s} / \mathrm{jam})$ $=22,08 \mathrm{~kW}$

\section{Panas Dari Motor Kipas Evaporator}

Untuk mengetahui jumlah panas yang dikeluarkan kipas evaporator maka diketahui daya input motor yang digunakan, dari maka itu panas motor kipas evaporator bisa dihitung sebagai berikut:

Motor head again : $520 \mathrm{~W}$

Qmotor $=0,52 \mathrm{~kW}$

Sehingga beban total keseluruhan yang ditambahkan ke ruang pendingin tersebut dapat dihitung dengan menjumlahkan sejumlah panas yang telah dihitung tersebut diatas:

Qtotal $\mathrm{ABF}=\mathrm{Q}$ dinding $+\mathrm{Q}$ atap $+\mathrm{Q}$ produk $+\mathrm{Q}$ motor

$$
=0,404+0,127+27,49+0,52
$$$$
=28,54 \mathrm{~kW}
$$

Dari perhitungan tersebut didapat nilai kapasitas pendingin evaporator lebih besar dari pada ABF yaitu $30 \mathrm{~kW}$, sedangkan beban pendinginan ABF pada tanggal 25 april sebesar 28,54 kW (untuk masa ikan $3.500 \mathrm{~kg}$ ).

\section{PENUTUP}

\section{Kesimpulan}

Berdasarkan data pengukuran, perhitungan, dan analisis yang telah dilakukan pada bab-bab sebelumnya diatas, maka dapat diambil beberapa kesimpulan sebagai berikut :

1. Dengan beban pendingin 1 ruang $\mathrm{ABF}$ sebesar 28,54 kW dengan massa ikan $3.500 \mathrm{~kg}$. Sudah cukup untuk normal untuk 1 ruang pendinginan $\mathrm{ABF}$

2. Sedangkan untuk COP aktual yang dicapai oleh $\mathrm{ABF}$ tersebut adalah sekitar 2,8 lebih kecil dari COP carnot yang besar 6,1. Hal ini disebabkan oleh panas yang didapat dari beban penyerapan panas produk dan lain-lain didalam evaporator lebih kecil dari pada beban penyerapan panas yang di ambil di evaporator dan di kompresor
3. COP (Coeffisien of Perfomance) adalah nilai perbandingan antara kapasitas penyerapan panas yang terjadi di evaporator dengan jumlah kerja kompresi yang dilakukan di kompresor. Untuk COP carnot merupakan nilai ideal dengan mengganggap bahwa kalor yang dilepas di kondensor adalah samadengan kalor yang diambil di evaporator ditambah energi yang dikeluarkan di kompresor.

\section{Saran}

1. Sistem refrigerasi diatas kapal lebih diperhatikan lagi tentang pengoperasiannya.

2. Skema pada refrigerasi diatas kapal masih kurang efektif dikarenakan susah untuk diperbaiki jika ada kerusakan atau kebocoran.

3. Alat keselamatan yang ada di atas kapal sangat minim.

4. Alat keselamatan untuk pekerja sangat minim.

5. Waktu istirahat selama berada dikapal kurang bahkan bisa membahayakan kesehatan pekerja.

\section{Ucapan Terima Kasih}

Penulis mengucapakan sebesar-sebesarnya kepada seluruh civitas akademik Politeknik Kelautan dan Perikanan Dumai yang telah memberikan dukungan, baik doa maupun saran dalam menyelesaikan artikel ini.

\section{DAFTAR PUSTAKA}

Hasbi G Al MM Budianto U, Amiruddin W. 2016. Analisa Unjuk Kerja Desain Sistem Refrigerasi Kompresi Uap Pada Kapal Ikan Ukuran 5 GT di Wilayah Rembang. Jurnal Teknik Perkapalan. Vol 4 No 4. Hal 768778.

P.Rambun.A, Sunarto, Nurruhwati.I. 2016. Selektivitas Alat Tangkap Purse Seine Di Pangkalan Pendaratan Ikan (PPI) Muara Angke Jakarta. Jurnal Perikanan Kelautan. Univesitas Padjadjaran. Vol.VII No 2.Hal.97-102.

Riswanto. (2017). Apa itu blast freezer dan apa kelebihannya. Retrieved from 
http://tegerteknik.com/blog/apa-itu-airblast-freezer-dan-apa-kelebihannya.html.

Rahmat. M. R, 2015. Perencanaan Cold Storage Untuk Produk Reagen. Jurnal Ilmiah Teknik Mesin, Vol 3, Universitas Islam 45 Bekasi.

Siagan. S, 2017. perhitungan beban pendingin pada cold storage untuk penyimpanan ikan tuna pada PT.X. Bina Teknika. Vol 13 No 1. hal 139-149.

Siagian S. 2015. Analisis Karakteristik Unjuk Kerja Kondensor Pada Sistem Pendingin (air conditioning) yang Menggunakan FFreon R-134 a Berdasarkan Pada Variasi Putaran Kipas Pendingin. Bina Teknika. Vol 11 No 2. Hal 124-130.

Tampubolon.D, Samosir.R. 2005. Pemahaman Tentang Sisem Refrigerasi. Jurnal Teknik Mesin. Politeknik Negri Medan.

Yunianto B. 2005. Pengaruh Perubahan Temperatur Evaporator Terhadap Prrestasi Air Cooled Chilled Dengan Refrigerant R134a, Pada Temperatur Kondensor Tetap. Jurusan Teknik Mesin. Vol 7 No 3. 